\title{
Committee volunteer form
}

One of ACRL's greatest strengths is the active involvement of our membership in committee and other volunteer activities. Each spring, the president-elect or section vice-chairs appoint members to fill vacancies on committees. For the editorial and publication advisory boards, appointments are made by the Publications Committee, based on recommendations from the respective editors.

The ALA Handbook of Organization contains a specific charge defining the work of each committee, task force, and editorial board. The ACRL Guide to Policies and Procedures contains a section on the appointment process.

I am willing to serve on any committee for which I am qualified and needed.

I am willing to serve as an intern on a committee.

Date of Application:

Name:

Job title:

Daytime phone:

Fax number:

E-mail address:

Organization/library:

Institution's address:

Ethnicity (optional):
The following divisionwide committees have vacancies annually. Please indicate your first three choices by marking "1," "2," and " 3 " on the corresponding lines.

Academic Library Statistics

Academic Status

Appointments and Nominations

Budget and Finance

Colleagues

Conference Program Planning

Constitution and Bylaws

Copyright

Government Relations

Image Enhancement

Intellectual Freedom

International Relations

Media Resources

Membership

Orientation

Planning

Presidents Program Planning

Professional Education

Professional Liaison

Publications

Racial and Ethnic Diversity

Research

Standards and Accreditation

\section{Awards}

Academic or Research Librarian of the Year

(Hugh C.) Atkinson Memorial Award Doctoral Dissertation Fellowship

(Samuel) Lazerow Fellowship for Research in Acquisition or Technical Services

(K.G.) Saur Award for Best College and Research Libraries article 
The 17 sections of ACRL have committee openings usually on an annual basis. Please look at the ALA Handbook of Organization for a listing of the section committees. To indicate your particular interest, write the committee name(s) next to the section listed below.

Afro-American Studies Librarians

Anthropology and Sociology

Arts

Asian, African and Middle Eastern

Bibliographic Instruction

College Libraries

Community and Junior College Libraries

Education and Behavioral Sciences

English and American Literature

Extended Campus Library Services

Law and Political Science

Rare Books and Manuscripts

Science and Technology

Slavic and East European

University Libraries

Western European Specialists

Women's Studies Section

\section{Background information}

On a separate single sheet of paper briefly summarize your background and activities in the following areas: 1) ALA professional activities; 2) ACRL professional activities; 3) state and regional offices held and committee appointments; 4) educational background and/or other experience that will assist the committee in the appointment process; 5) publications; 6) express your professional concerns and the contribution that you can make toward strengthening ACRL; 7) list any other professional organizations to which you belong; please indicate those organizations (if any) for which you would be willing to serve as the ACRL liaison.

\section{Note: Membership in ALA and ACRL is required. Attendance at Midwinter Meeting and Annual Conference is required.}

Return this form to: (Use duplicate forms if you are interested in both a standing committee and a section appointment.)

ACRL section committees: If you would like to serve on a section committee, send this form to the appropriate vice-chair/chair-elect (listed on pages 589-590) before December 15, 1994 You must be a member of the section to be considered for appointment.

Standing committees: If you are interested in serving on one of the standing committees, complete this form and return it to: Maxine Reneker, 437 College Ave., Palo Alto, CA 943061525; (408) 656-2341; fax: (408) 656-2842; e-mail: mreneker@nps.navy.mil. Forms must be returned by December 15, 1994, for you to be considered for appointment. 


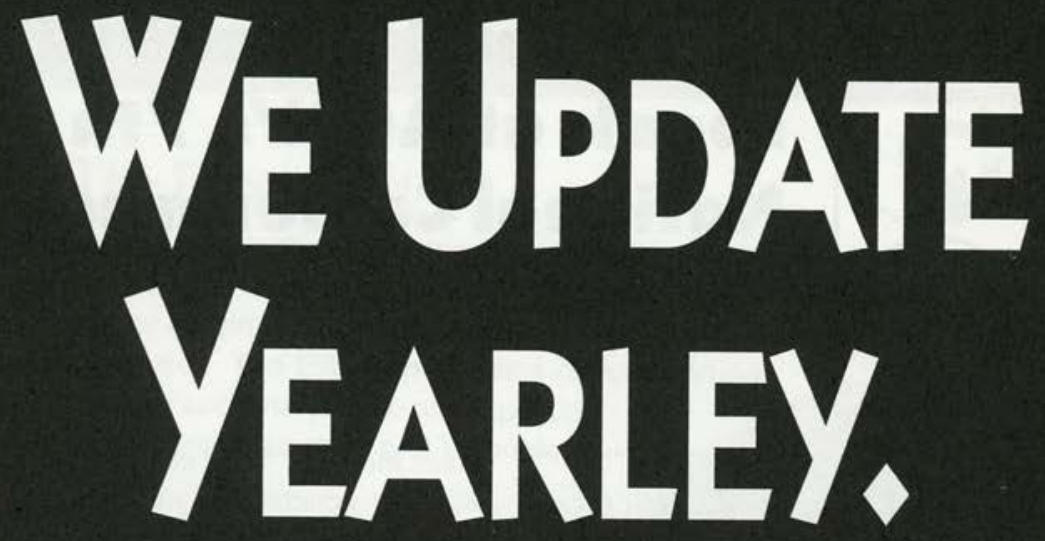

\section{(And over 90,000 other names found only in the new, 1995 edition.)}

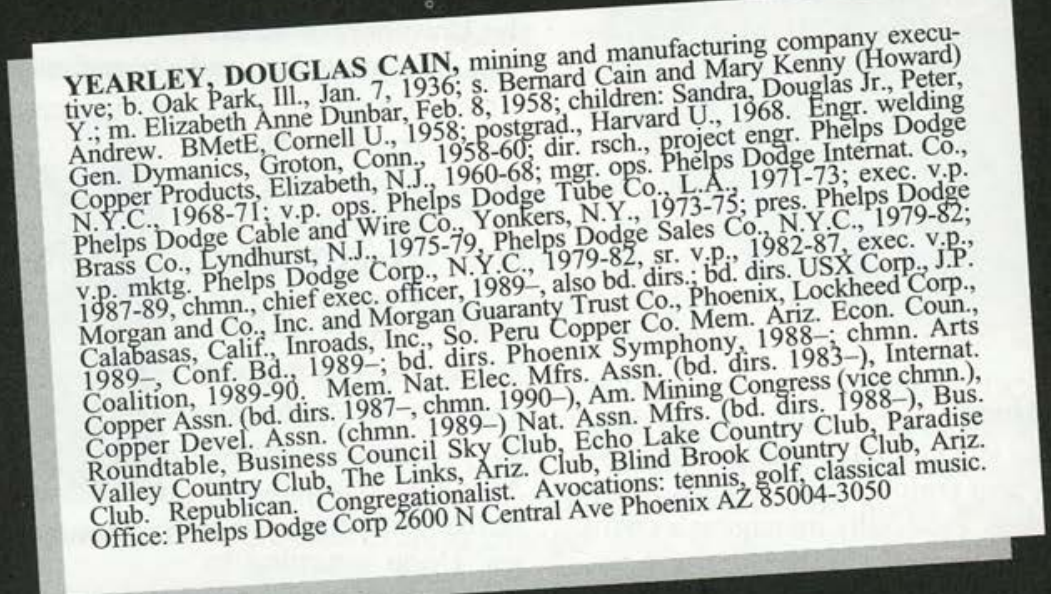

A lot can change in a year-especially when it comes to people in the public spotlight. That's why Marquis Who's Who in America, is now published yearly.

\section{This year alone} there are over 16,000 new entries and 61,000 updated biographies. And the changes don't stop there. Researchers will

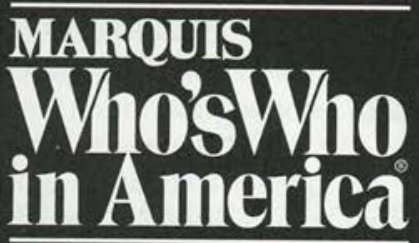

A REED REFERENCE PUBLISHING COMPANY now be able to take advantage of another innovation-the Geographic/Professional Index is now included at no extra charge. It's no wonder that since 1899 , more

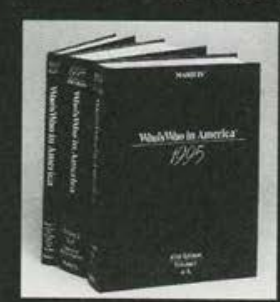
researchers turn to Who's Who in America as America's foremost biographical reference.

To order your 1995 edition, call 1-800-521-8110 today. 